\title{
Kairós e Carnaval: curso da vida, regimes de visibilidade e condutas homossexuais no Pantanal de Mato Grosso do Sul
}

\author{
Guilherme Rodrigues Passamani \\ Professor Adjunto I da Universidade Federal de Mato Grosso do Sul
} grpassamani@gmail.com

\begin{abstract}
Resumo Neste artigo, apresento a particularidade do kairós do carnaval em Corumbá, entendendo-se por kairós um tempo especial, tempo de oportunidades, aquele que permite a construção de algo diferente do ordinário. A partir de uma pesquisa etnográfica realizada entre 2012 e 2014 na região do Pantanal de Mato Grosso do Sul, destaco a importância do carnaval para as pessoas com condutas homossexuais, especialmente as mais velhas, que compuseram a minha investigação. Primeiramente, atendo-me às noções de cronos e kairós, mostro como o carnaval constitui um tempo de protagonismos. Logo em seguida, destaco como ele é compreendido por meus interlocutores e pela literatura da área. Por fim, analiso as lembranças que, no imaginário da região, constroem o carnaval como o lugar das "bichas" e levam a uma associação do tempo da festa com a juventude.
\end{abstract}

Palavras-chave: Carnaval, curso da vida, condutas homossexuais, sexualidade, Pantanal.

\section{Introdução}

66 O carnaval de Corumbá é grande porque é tocado por homossexuais. Eles estão em todas as escolas. São competentes. São a alma do carnaval. Desde o começo foi assim." Esta é uma fala de Mauro (67 anos), um dos interlocutores que entrevistei para a reflexão que pretendo aqui desenvolver. Conhecemo-nos pela internet. Mauro é um homem branco, magro, comerciante na cidade de Corumbá e foi um dos colaboradores de minha pesquisa de doutorado. ${ }^{1}$ Para ele, em Corumbá, o carnaval é o locus das "bichas", e a festa só tem a dimensão que tem em função desses sujeitos. Portanto, pensar o carnaval nessa cidade, na perspectiva dele, é pensar a atuação e o protagonismo das pessoas com condutas homossexuais.

1. Este artigo é um exercício reflexivo que tem como origem uma pesquisa maior. Da pesquisa maior, resultou a minha tese de doutorado em Ciências Sociais (IFCH-Unicamp, 2015). Nela, problematizei a intersecção entre envelhecimento, regimes de visibilidade e condutas homossexuais na região do Pantanal do Mato Grosso do Sul, nas cidades de Corumbá (108 mil habitantes) e Ladário (21 mil habitantes). Durante o trabalho de campo, foram contatadas, nas duas cidades, 17 pessoas com condutas homossexuais e com idade variando entre 52 e 82 anos. A participação delas ajudou-me a pensar trajetórias, curso da vida e possíveis idiossincrasias na experiência de sujeitos que apresentam o perfil descrito e habitam regiões que não são caracterizadas como grandes centros urbanos (Passamani, 2015). 
Tomando essa direção, o presente artigo tem por objetivo mostrar a particularidade do kairós do carnaval em Corumbá e os significados específicos que a "arte de viver" ganha naquele contexto. ${ }^{2} \mathrm{O}$ artigo está estruturado em três partes. Na primeira, recorro à filosofia sofística grega e à oposição entre cronos e kairós para apresentar a importância do carnaval enquanto tempo e espaço de protagonismos específicos ou, quem sabe, de alguns infortúnios indesejados.

$\mathrm{Na}$ segunda parte, enfatizo a forma como o carnaval tem sido compreendido dento da bibliografia sobre o tema, demonstrando que há um predomínio dos grandes centros urbanos como locus das investigações sobre essas manifestações. Além disso, procuro mostrar como os sentidos e os significados da festa são constituídos pelos mais velhos com condutas homossexuais no contexto corumbaense. Por fim, na terceira parte, exploro o modo como as lembranças são evocadas na perspectiva de construir o carnaval corumbaense como o lugar das "bichas" e destaco a associação estabelecida entre o tempo da festa e a juventude.

\section{Kairós e a "arte de viver"}

Como este artigo fala sobre tempo, foi necessário recorrer à filosofia sofística grega, especialmente, no que diz respeito aos significados de cronos e kairós. $\mathrm{O}$ cronos, para os antigos sofistas, era o tempo organizado cronologicamente, aquele que é composto por etapas sucessivas e lineares. Esse tempo é edificado a partir das ideias de passado, presente e futuro, ou seja, é composto de trajetórias. Ele representa o tempo com que, mais ou menos, nos identificamos e sob o qual somos socializados.

A antiguidade grega construiu uma representação, também, para tempos especiais, tempos de oportunidades, chamando-os de kairós. O kairós, então, representava aqueles momentos específicos em que eram exigidas decisão e ação. Está inscrito no cronos, mas não é similar a este. Segundo Michel Foucault (1988, 2001, 2005), o kairós marca a forma material e temporal de representação da ação dos sofistas, isto é, pensá-lo é uma maneira de criticar a separação, proposta por Platão, entre poder e saber.

O kairós é o tempo do instante, aquele que não tem retorno, o tempo que permite a construção de algo diferente do ordinário. Ele é específico. Estas concepções permitem pensar o carnaval em Corum- bá como um kairós, seja pelos protagonismos específicos, ou mesmo pelos infortúnios indesejados que surgem durante a festa. O "carnaval de antigamente" na região, possivelmente o momento em que tal especificidade do tempo mais salte aos olhos, talvez não tenha funcionado como um mero intervalo, como propunha Roberto DaMatta (1979), por exemplo; quem sabe tenha sido um tempo específico, completo em si mesmo e que produzia uma série de possibilidades de protagonismos e realizações para sujeitos que ordinariamente não eram protagonistas na mesma dimensão em que o eram durante a festa.

Os interlocutores desta pesquisa permaneceram na cidade de origem, Corumbá, em que pese alguma circulação pelas "cidades grandes". Sua visibilidade durante a permanência na cidade natal mostrava graus variados, sendo que, no período que aqui estou chamando de kairós do carnaval, chegavam a ser vistos como responsáveis por aquele tempo específico de realizações.

O carnaval não era meu tema preferencial de investigação. Ele se impusera como questão de pesquisa advinda do campo. Grosso modo, o que povoava meu imaginário eram algumas imagens estereotipadas sobre o envelhecimento e a velhice de pessoas com características homossexuais em Corumbá. Afloravam apontando as supostas distâncias abissais entre o modo como esta realidade, possivelmente, era compreendida no local e o que a configurava nos grandes centros urbanos. Apesar de me atraírem num primeiro momento, as imagens de velhinhos do grupo escolhido, saudosos de uma época de ouro, eram por demais comuns, sem grandes encantamentos. Afinal, isso poderia não ser nenhum absurdo numa pequena cidade sem qualquer sinal visível de um "mercado GLS" (espaços específicos para a sociabilidade de pessoas com conduta homossexual: gays, lésbicas e simpatizantes) (França, 2012), como o que prolifera nas capitais do Sudeste.

No kairós, categorias como "bichas", "homens" e "entendidos", que foram documentadas e cuidadosamente analisadas por pesquisadores clássicos no Brasil (Fry, 1982), eram formas de representação que serviam para alocar desejos e que, algumas vezes, desrespeitavam a estrutura do cânone. Alguns interlocutores desses estudos chegavam a compreender que o carnaval fora o lugar dos "últimos homossexuais", aqueles que estariam na terceira fase das práticas homossexuais, nos termos de Ernesto Meccia (2011). Sob a influência teórica do interacionismo simbólico e a partir de uma interlocução com sujeitos portenhos

2. Uso a expressão "arte de viver" de forma alegórica e tomada de empréstimo de Michel Foucault. O filósofo propõe a retomada do diálogo da filosofia com a literatura no curso "O governo de si e dos outros" (Foucault, 2004). Uma interessante problematização destas questões levantadas por Foucault pode ser vista em Tony Hara (2012). Na visão deste autor, a "Arte de Viver significa aproximar-se de si mesmo e, eventualmente, desprender-se de si, a fim de inventar novas saídas e novos sentidos para uma existência que, até então, se encontrava perdida, olhando mapas e desprezando horizontes" (p. 14). 
com mais de quarenta e cinco anos, Meccia apresenta tipos ideais de dois regimes de gestão das relações e práticas de pessoas com conduta homossexual. Estes regimes são nomeados por ele de "homossexualidade" e "gaycidade". Em meio às mudanças operadas no intervalo entre esses dois polos, existiria o que o autor chama de "três eras": "homossexual, pré-gay e gay”. Diferentes comportamentos, práticas e relações transcorridas durante as três fases determinariam o ritmo das transformações efetuadas nesse constante trânsito. Hoje, como dizem os interlocutores dos estudos sobre estas práticas, as "bichas" já teriam morrido, não porque não existem mais, mas porque os tempos mudaram e as representações já seriam outras. No contexto de Buenos Aires, Meccia (2011) destaca as trajetórias e performances dos últimos homossexuais. Já as particularidades da pesquisa em Corumbá mostraram que a espécie de linha do tempo da proposta mecciana foi completamente descronologizada ali.

O kairós do carnaval é sintomático para se perceber como as transformações sociais, que não cessam de ocorrer, acabam produzindo diferentes regimes de visibilidade para esses que podem, ou não, ser os últimos homossexuais no Pantanal. Diante de um imbróglio que não foi de fácil resolução, olhei para o carnaval como um cenário capaz de me propiciar pensar memória em intersecção com alguns marcadores sociais da diferença que me permitissem compreender as experiências vividas por meus interlocutores a partir do acionado por suas lembranças. Um cenário que, além disso, me proporcionasse subsídios para pensar os elementos que eles mesmos investem em determinado tipo de construção de si e atentar no cuidado com que manejam estas informações.

Não perdendo de vista o tempo kairós, interessava-me compreender algo como a "arte de viver" dos meus interlocutores, as saídas engendradas por eles para se aproximar de si mesmos e suas invenções de novos sentidos para a existência. Ou seja, quais elementos eles acionavam para se edificarem como sujeitos? Se não há um "destino manifesto" nas trajetórias dos meus interlocutores, há sim uma noção bem-estabelecida de curso da vida, há uma produção de certas regulações das experiências. No limite, tais regulações controlam um eu descentrado, fragmentado, multissituado, ainda que a vida esteja ou seja, em alguma medida, descronologizada, formada de experiências dispersas. ${ }^{3}$

Meus interlocutores partilham, além do carnaval, a vivência de uma época em que as experiências parecem bastante embaralhadas, e os momentos dessas experiências, ao longo da vida, não têm ocorrido da mesma forma, nem na mesma intensidade ou instante. Trata-se, pois, de um rompimento com o cha- mado curso da vida moderno e com o estabelecimento de fases perfeitamente delimitadas (Bassit, 2000).

Conforme Guita Debert (2004), opera-se uma mudança no modo como a vida é periodizada. Este contexto, que, a partir de Harry Moody (1993), é chamado de "curso da vida pós-moderno", mostra que as experiências convencionais de determinadas idades foram embaralhadas ou borradas, quer dizer, não há mais uma "idade certa" para realizações específicas. O mundo contemporâneo, então, vive da representação daquilo que mais interessa, ou seja, vive do que interessa ser contado sobre momentos específicos da vida.

Há um "desemparceiramento" da vida, isto é, uma espécie de desestruturação, algo próprio da ideia quase biológica de curso da vida moderno. Esse processo traz um desafio de fundo, que é, justamente, reservar espaço para as experiências vividas, para as relações estabelecidas e para as imponderáveis influências culturais que se apresentam na vida de todas as pessoas sem que isso possa ser previsto. O curso da vida, então, permite um lugar para a diferença, para as múltiplas manifestações da experiência.

Manejar o conceito de curso da vida, neste artigo, é fundamental em dois sentidos: primeiro, porque o contato com as diferentes gerações de interlocutores na região do Pantanal torna possível perceber o processo de mudança do conceito de "homossexualidade como lugar social” (Carrara, 2005). Segundo, porque no curso da vida dos interlocutores são perceptíveis diferentes regimes de visibilidade no que diz respeito à orientação sexual.

Por meio do curso da vida, é possível articular este kairós do carnaval que meus interlocutores trazem como parte relevante de seus percursos biográficos. E assim, tal como Mike Featherstone e Mike Hepworth (2000), estou na contramão de uma concepção dominante de curso da vida, pois, justamente, estou problematizando tempos que não são linearmente estabelecidos. O kairós do carnaval pode ajudar a compreender não apenas o curso da vida e suas diferentes formas de "escrita" em cenários não centrais, como é o caso que trago aqui, mas também a maneira como esse curso da vida pode ser vivenciado entre sujeitos com condutas homossexuais na região investigada.

\section{Kairós do carnaval}

O kairós do carnaval é um momento em que sobressaem as diferenças, as tramas entre diferenças e a visibilidade de diferenças. O carnaval é uma festa com séculos de história. Há registros de que ele exis-

3. Para uma compreensão sintética dos olhares emitidos pela História, Psicologia do Desenvolvimento e Sociologia do Envelhecimento sobre o curso da vida, ver Giele e Elder (1998). 
te, pelo menos, desde os anos de 1600 em diferentes regiões da Europa. Essa festa chega ao Brasil a partir da colonização portuguesa. Além-mar, especialmente em Portugal, também era conhecida pelo nome de entrudo, que significa entrada. Isso porque o carnaval marcaria a entrada da primavera (Queiroz, 1992). Em terras brasileiras, tornou-se tão popular a ponto de o Brasil intitular-se "o país do carnaval". Entre nós, a tradição europeia dos festejos ganhou o acréscimo de elementos de matriz africana que estilizaram o evento (Queiroz, 1992).

Alguns pesquisadores afirmam que o carnaval é a "festa popular por excelência" (DaMatta, 1979) e que, nos dias de festa, há uma inversão da pirâmide social, uma horizontalização de nossa hierarquia de classes, ou uma "feminização do mundo". Maria Isaura Pereira de Queiroz (1992) conta que, não obstante estas afirmações, até o século XIX, a marcação de classe era bastante sintomática no período do carnaval, tendo em vista que o preparar-se para os festejos demandava vultosos recursos financeiros. Dessa forma, parte significativa das pessoas permanecia excluída do processo.

O carnaval pode, na maioria dos casos, sedimentar as diferenças entre os diversos grupos de foliões. Logo, pode servir como um kairós que potencializa as diferenças antes de torná-las sutis. Mais do que uma inversão nos lugares da pirâmide social, ou mesmo na hierarquia de gênero, talvez o que o carnaval possibilite sejam momentâneos instantes de inversão de protagonismo de alguns sujeitos. Isto é muito diferente de mexer nas estruturas de classe e de gênero, que são mantidas de forma tácita.

Muito oportuno, a este respeito, é um texto de Peter Fry e Edward MacRae (1978), intitulado "Mesmo no carnaval baiano, cada macaco no seu galho". $\mathrm{Na}$ contramão das teses da inversão, os autores procuram pensar o carnaval como um "ritual de rebelião". E essa rebelião não diz respeito a inverter estruturas, mas sim a processos, inclusive, processos territoriais de dominação espacial momentânea: aqueles "que transam", ou seja, as pessoas com conduta homossexual, saem das periferias, dos lugares escondidos e apropriam-se do centro da cidade na capital baiana.

Esta gente "que transa" sai das periferias (geográficas, sociais e de gênero) para fazer, de fato, o carnaval. Contudo, ao final da festa, na Quarta-Feira de Cinzas, tudo volta ao seu devido lugar. Portanto, na visão dos autores, o que houve foi apenas um câmbio de protagonismos que, ao fim e ao cabo, confirma a lógica estrutural do poder, que acaba por se manter.

O carnaval ganha diversas cidades do Brasil. Chega, inclusive, ao Pantanal. Ali, ele marca a vida de alguns dos meus interlocutores. Um deles, Tatá (pardo, gordo, de 53 anos, assalariado do setor de serviços), embora não se envolva mais com o carnaval, diz que a festa tem uma importância quase mística e que sua tradição é muito forte na cidade. Isso se explica, em sua visão, pelo considerável volume de recursos financeiros que são movimentados nessa época, inclusive, porque o carnaval de Corumbá, como ele afirma, com eco em outras falas, é considerado o melhor carnaval de Mato Grosso do Sul.

Alguns interlocutores envolvidos com o carnaval de Corumbá contam que os seus primórdios remontariam à metade do século XX e à ligação da região com a Marinha, por existir em Ladário o $6^{\circ}$ Distrito Naval. Todo o povo da Marinha que chegava a esse distrito vinha do Rio de Janeiro, sede desta instituição. As transferências na Marinha, via de regra, costumam sempre passar por esta cidade, onde o carnaval é uma tradição imbatível. Quer dizer: se um marinheiro está no norte do país e quer ir para o sul, antes ele precisa passar um tempo no Rio de Janeiro. Toda e qualquer transferência se dá dos distritos para a sede e da sede para os distritos. Esse fato gera uma forte presença de cariocas na região do Pantanal e por isso ocupa um lugar assemelhado ao de um mito fundador do carnaval na região. Segundo meus contatos de campo, especialmente aqueles que participam do que convencionei chamar de "mundo do samba", os marinheiros que eram transferidos para Ladário tinham o hábito de fazer festas em suas casas nos finais de semana. Essas festas reuniam diferentes grupos de marinheiros, bem como as pessoas locais com quem eles começavam a travar algum tipo de relação mais próxima.

A música que animava as festas era o samba, algo característico do lugar de onde vinham os novos moradores do Pantanal. Essas festas, ritmadas pelo samba, foram se tornando habituais e extrapolando os fundos dos quintais das casas dos marinheiros, ganhando a cidade e transformando-se nos pagodes, que até hoje são frequentes em Corumbá. As festas improvisadas nos fundos da própria casa, ao som do samba, aliadas à saudade do Rio de Janeiro e do carnaval que lá se fazia, teriam funcionado como uma espécie de válvula propulsora para tentativas iniciais de organização das primeiras escolas de samba. Tito (branca, magra, de 52 anos, travesti e carnavalesca) relata:

Por isso que as pessoas falam que Corumbá tem um quê de Rio de Janeiro. Por causa disso, das pessoas que eram transferidas de lá pra cá, da Marinha. Gostavam de samba, sambavam, não sei o quê. Então, as pessoas foram se identificando. Tanto é que o povo vinha transferido do Rio de Janeiro, casava aqui, por aqui mesmo ficava, então é assim. Eles trouxeram o carnaval e Corumbá adquiriu esse hábito de carnaval. Os marinheiros gostam porque eles vêm do Rio de Janeiro e têm assim uma raiz, né? Uma identificação com eles. 
Os marinheiros, então, teriam transposto para o Pantanal a tradição do samba, mas, mais que ela, o gosto pelo carnaval. Com o passar dos anos, este gosto foi sendo aprimorado, até que o carnaval se tornou uma festa popular na região. Tito, carnavalesca com quem conversei algumas vezes, diz que o pioneirismo no carnaval da região foi de Ladário, onde os primeiros blocos teriam sido formados por marinheiros e amigos. Pouco tempo depois, em vista do desenvolvimento de Corumbá, a festa migraria para esta cidade maior. Houve em Corumbá uma mística reinvenção do carnaval carioca em terras pantaneiras. Esta reinvenção não foi uma transposição automática e nem completamente fiel. Houve uma série de adaptações à realidade da região.

Meus interlocutores lembram que, em Corumbá, diferente dos cortes elitistas que outros estudos observaram, os primórdios do carnaval possibilitaram aos pobres, negros e "marginais"4 o lugar de protagonistas do espetáculo - o que não quer dizer que não exista nessa festa a construção de hierarquias outras. Isso se aplica especialmente aos blocos e às escolas de samba. Nesses lugares é que estavam as pessoas com conduta homossexual, ou "viados", e as mulheres chamadas de "putas". Majoritariamente, conforme o relato dos interlocutores, estes sujeitos eram mais escuros, negros ou pretos, categorias acionadas para demonstrar a ausência de sujeitos brancos. Os relatos que apurei em campo, na contramão de Queiroz (1992), mostram que os ricos em Corumbá eram os espectadores da festa. As "boas famílias" ou estavam no Corso, desfilando seus carros enfeitados, ou na assistência, vendo "a banda passar".

Os "carnavais de antigamente", a que se referem alguns dos meus interlocutores e também os interlocutores de Fabiano Gontijo (2009), são os carnavais preferidos. Talvez, concretamente, por serem impossíveis de acessar outra vez, senão pelas ferramentas da memória, que lhes permitem contar e reviver a festa como eles acharem melhor. Tal especialidade me faz insistir na ideia de que o tempo do carnaval é um kairós específico, um tempo de oportunidades e realizações, mais do que apenas um intervalo do cronos convencional.

Quando se reportam aos carnavais de antigamente, tempo que nunca é descrito de forma muito definida, os interlocutores, especialmente Deco (branco, magro, de 53 anos, funcionário público), falam de um carnaval que "acontecia", que "não era feito". O acontecer do carnaval tem muito a ver com iniciativas espontâneas de diferentes grupos de pessoas, sem muito cuidado com a infraestrutura, ou mesmo com a institucionalização e a profissionalização da festa. Ela tinha um caráter mais amador e mais instrumental. Essa é uma diferença marcada entre o carnaval antigo e o de hoje, que "é feito" pela Liga Independente das Escolas de Samba de Corumbá (Liesco) e pela Liga Independente dos Blocos Carnavalescos de Corumbá (Liblocc), além de contar com todo um aparato do poder público da cidade.

Nos anos de 1970, recordam alguns interlocutores, o carnaval de Corumbá contava com blocos, cordões e escolas. ${ }^{5}$ Os blocos seriam as organizações mais simples e mais populares. Especialmente, são citados os "blocos de sujos", em que os homens se "vestem de mulher", as mulheres "se vestem de homem" e as fantasias não demandam muitos gastos. São blocos muito populares na cidade até hoje e alguns reúnem perto de quinze mil pessoas. Esse tipo de organização carnavalesca, segundo James Green (2000), foi muito importante no começo da apropriação do carnaval carioca pelos homossexuais, pois permitiu os primeiros ensaios de visibilidade para esses sujeitos.

Os interlocutores contam que gostavam de desfilar no bloco de sujos Cibalena, um dos mais conhecidos da cidade e que concentrava um número elevado de pessoas. Eles lembram que o Cibalena, nos seus "tempos gloriosos", era composto apenas por homens. Eram cerca de quinze mil homens "vestidos de mulher". Entre estes milhares de homens, segundo eles, havia muitas "bichas incubadas", 6 que passavam o ano todo esperando a chegada do carnaval para colocar a roupa da irmã e "bichar" um pouco. ${ }^{7}$ Atualmente, o bloco aceita a presença de mulheres, pois se transformou em um bloco misto.

O Cibalena era o bloco dos homens adultos. No entanto, havia um grande número de adolescentes que tentavam se inserir no bloco, apesar de não conseguirem, por não estarem ainda em idade adulta. E, segundo os relatos de alguns dos meus interlocutores, esses adolescentes já despertavam o interesse deles. Esses jovens, então, fundaram um bloco de sujos para si e fizeram muito sucesso. Era o Bloco da Chupeta, clara alusão aos bebês. O bloco de sujos dos adolescentes saía no dia anterior ao desfile do Cibalena.

Os interlocutores do grupo dos mais velhos contam que esperavam pelo Chupeta para ver as "bichinhas novas" que estariam se preparando para o Ciba-

4. Quando falo em marginais, estou fazendo referência a todos os sujeitos que, de alguma forma, não se inserem nas normas morais vigentes, estabelecidas por determinado grupo social que consegue fazê-las socialmente legítimas.

5. Sobre as diversas formas de organização dos grupos sociais no carnaval, ver Queiroz (1992) e Gontijo (2009).Ver ainda Fabiano Gontijo (2009), que problematiza blocos e bandas no carnaval carioca nos anos de 1990, bem como a presença de pessoas com conduta homossexual.

6. "Bichas" ainda "não assumidas", as que "estão no armário", ou homens socialmente reconhecidos como tendo conduta heterossexual, mas que as "bichas mais experientes sabem que são bichas".

7. Sobre o verbo "bichar", ver Isadora França (2012). 
lena ou para as escolas de samba em anos posteriores e confessam nunca terem sido enganados por uma fantasia ou por uma "virada de mão" de carnaval. Segundo eles, sabiam reconhecer claramente o que era "transgredir" somente durante a festa, em oposição aos sinais diacríticos de uma suposta identidade de "bicha incubada".

\section{Carnaval como lugar das "bichas"}

Todos afirmam, em uníssono, que a presença das "bichas" no carnaval de Corumbá é recorrente desde os primórdios da festa. As pessoas com conduta homossexual, em alguns momentos, de forma mais visível, em outros, de forma mais "incubada", teriam sido os sujeitos responsáveis pelo dinamismo e pela criatividade que envolvem o carnaval da cidade. Salienta-se, no entanto, que os primeiros carnavais eram mais difíceis, pois havia na região certo preconceito contra as pessoas que apareciam na festa.

O trabalho histórico de James Green (2000) é interessante ao destacar a apropriação que os "homossexuais" fizeram do carnaval carioca. Green está pensando exclusivamente sobre o Rio de Janeiro. Entretanto, alguns dos seus achados neste processo ecoam para outros lugares do país, dada a visibilidade do Rio de Janeiro, naquele momento, anos de 1960, para as pessoas com condutas homossexuais em outras regiões do Brasil.

O carnaval com a presença de pessoas com conduta homossexual é resultado de um longo processo de ganho de espaço e visibilidade por esse conjunto de sujeitos. Há os primeiros shows de transformismo, os bailes de travestis, a chegada em massa de indivíduos com comportamento homossexual para bailes que não eram "genuinamente gays" e finalmente a conquista de espaços definitivos e exclusivos, especialmente nas escolas de samba. O ponto de partida desse processo, no entanto, foram as reuniões particulares entre pequenos grupos de amigos. No carnaval carioca, por exemplo, os "homossexuais" teriam tornado possível o contato com outros grupos de foliões nesta "arena pública da visibilidade". 8 Todavia, mesmo a partir dessa visão, não se trata de um processo de inversão da pirâmide social nem de uma communitas, já que as diferenças eram mantidas e, em alguns casos, até ressaltadas (Green, 2000).

Meu interlocutor Deco conta que, no carnaval de Corumbá, as mulheres eram taxadas de "putas" e os homens, de "viados". Não apenas por ser aquele um momento de transgressão, como alguns apontam, mas, sobretudo, porque isso tornava a sexualidade mais aparente em um lugar onde ainda vigorava determinada moral que velava por princípios religiosos sensíveis e não entendia o carnaval como um espaço apropriado para "pessoas de bem".

É questão corrente entre meus interlocutores que em Corumbá a situação foi complicada nos primeiros tempos da festa, mas que, nas décadas mais recentes, ela dá sinais de transformação. E tanto é assim que Mauro,que não está muito atuante no carnaval atualmente, observa na festa bastante influência das pessoas com conduta homossexual:

O carnaval de Corumbá é grande porque é tocado por homossexuais. Eles estão em todas as escolas. São competentes. São a alma do carnaval. Desde o começo foi assim. O carnaval era a época que toda bicha esperava para poder sair de casa, sair na rua, se vestir de mulher. A gente esperava o carnaval para acontecer. Se você for ver, todo mundo tem história de um carnaval. Todas têm um amor de carnaval. Era nesse momento que a gente se sentia livre. Passava o ano inteiro tendo que agir na noite. No carnaval era tudo durante o dia, todos os dias. É como se as fantasias virassem a realidade. Era um tempo de não preconceito. A grande manifestação gay de Mato Grosso do Sul é o carnaval de Corumbá.

Mauro aciona uma série de elementos que valoram o carnaval não apenas como uma grande festa na cidade, mas também como uma festa em que a sexualidade daqueles "que transam" (Fry; MacRae, 1978) ocupa um lugar de protagonismo. O interlocutor também vê o carnaval como a possibilidade de agir "durante o dia, todos os dias", isto é, um tempo de apropriação de um momento e de um lugar que, costumeiramente, não são seus. Durante aquela semana de festa, podia-se realizar uma série de atividades, sobretudo no campo dos desejos homoeróticos, que, nos outros dias do ano, talvez, fossem proibidos, indesejados ou facilmente reprimidos. Está aí uma das particularidades desse kairós do carnaval. Segundo Mauro, cuja fala encontra eco em outras vozes, desde a construção da festa em si, quase sempre pelas pessoas com conduta homossexual das escolas de samba e outras agremiações, até a performance dos foliões, o carnaval era uma época diferenciada.

Instigante pensar um evento determinando uma série de processos que acabam por modificar a compreensão do tempo. O kairós do carnaval é completo em si mesmo, com suas oportunidades, com suas realizações e até com seus infortúnios, mas completo em si mesmo. Um tempo dentro do tempo, e não uma fatia entre dois tempos. 
Na voz de minha interlocutora Tito, o "tempo do carnaval" permite que as pessoas "liberem geral". Segundo ela, "os homens vivem guardados no armário. Então, eles esperam, o ano inteiro, o carnaval para colocar uma minissaia". A fala sugere que colocar uma minissaia, muito mais do que transitar entre os gêneros, representaria a viabilização de uma vontade erótica e sexual pelo mesmo sexo. Tito diz que muitos são os casos que ela poderia contar sobre "os homens mesmo, que sentem vontade, mas não têm coragem" e só se permitem isso no carnaval. A interlocutora refere-se a um "tempo de permissão", possível durante o festejo.

As "primeiras bichas", segundo alguns interlocutores, especialmente Tom (pardo, magro, de 54 anos, funcionário público), foram as desbravadoras. Estiveram presentes nos piores momentos, quando não havia aceitação, quando eram ridicularizadas, apontadas e até humilhadas. Elas abriram as portas para que as "novinhas" pudessem viver carnavais menos inóspitos e mais receptivos. "Foram elas as vítimas dos risos sarcásticos, do deboche e dos xingamentos, e isso nós devemos respeitar. São nossos baluartes."

Tom lembra que o simples fato de eles desfilarem com as fantasias que denotavam algum luxo já os qualificava como homens com conduta homossexual e os tornava passíveis de algum xingamento pelas pessoas "estranhas ao meio". Em contrapartida, as "bichas incubadas", ou mesmo as "novinhas", ao ver aquelas figuras altivas no carnaval, segundo ele, sonhavam em ser, alguns anos depois, tal como elas, as protagonistas da festa. ${ }^{9}$

Estas primeiras pessoas com conduta homossexual, ao se tornarem visíveis no carnaval, serviam de espelho ou referência para um sem-número de sujeitos que começavam a sentir desejos "disparatados", vontade de fazer parte da festa com fantasias cheias de plumas, paetês, botas e salto alto. Mas, embora pudessem achar "muito lindos" estes adereços, a realidade talvez lhes aconselhasse a silenciar-se sobre tais gostos ou preferências.

Portanto, para alguns interlocutores, os primeiros lugares eram justamente os de espectadores, lugares relativamente confortáveis e que lhes garantiam certo distanciamento dos xingamentos e humilhações enfrentados pelos pioneiros, mas igualmente os mantinham distantes do brilho e da visibilidade que as protagonistas da festa desfrutavam. Hoje, porém, segundo Tom, os tempos são outros: "Hoje em dia eles [os populares na rua] não xingam mais. Muito difícil. Se você sai, se coloca um salto alto no dia, um biquíni e sai a desfilar assim, os bofes vêm tudo atrás no carnaval. Nossa, as bichas ficam no auge aqui. Sempre".
Histórias sobre o carnaval, sobre os afetos, sobre os amores surgidos são muitas. No entanto, há um ponto que chama mais a atenção na fala de Tom: é esta transformação, este momento em que o xingamento e a vergonha dão lugar ao aplauso e ao orgulho, algo como os trânsitos entre os regimes propostos por Meccia (2011) ao comentar o caminho da "homossexualidade" à "gaycidade". Isso talvez se deva à popularização alcançada pelo carnaval entre as pessoas e mesmo no imaginário da região. À medida que a festa vai sendo incorporada por um grupo maior de simpatizantes, ela deixa de reproduzir antigos rótulos de desprestígio para as mulheres e para as pessoas com conduta homossexual.

O carnaval representaria o que meus interlocutores chamam de "glamour para as bichas". Quando busco saber o que seria esse glamour e quais seriam essas "bichas glamorosas", consigo visualizar um pouco melhor do que alguns interlocutores falam. $\mathrm{O}$ carnaval, como momento de realização de fantasias e sonhos, seria o "palco iluminado" de todas as "bichas que sempre perderam na vida". Porque elas eram homens afeminados numa sociedade que exige discrição dos homens com conduta homossexual; porque possuíam corpos fora dos padrões hegemônicos de uma estética de beleza valorizada numa sociedade hedonista que cobra músculos e definições corporais extremas; porque eram pretas ou pardas num mundo em que a expectativa era por brancos; porque eram pobres num círculo onde se esperava ricos.

O "glamour das bichas" diria respeito, segundo os interlocutores, à possibilidade de sair da periferia e desfilar pelas principais ruas do centro da cidade, tal como observaram, em Salvador, Peter Fry e Edward MacRae (1978). Desfilar suas ausências, num tempo que logo se esvai, portanto desfilar com emergência. Glamour às avessas, marcado por classe, raça, padrões estéticos, convenções de gênero e sexualidade. Tempo de diferenças descobertas, em que as classes normalizadoras, quase num rito, concedem permissão para a festa acontecer naquele tempo quase liminar. Um intervalo em que as travestis são retiradas das esquinas de "batalha" e coroadas como as "donas" e criadoras da festa.

Das lembranças de carnaval que marcaram os interlocutores da pesquisa, sem dúvida, a mais sintomática era a Batalha de Confete, uma espécie de "aquecimento" para a festa. No mês de janeiro, as escolas de samba iam para a avenida onde ocorriam os desfiles para apresentar o novo samba, mas com fantasias dos anos anteriores. O espetáculo era mais improvisado e tinha o intuito de fazer com que o samba fosse decorado pelo público e os foliões fossem se familiarizando com algumas marcações na "passa-

9. Os apontamentos de James Green (2000) sobre os concursos de fantasias de luxo durante o carnaval são muito interessantes. Via de regra, quem desfilava estas fantasias eram pessoas com conduta homossexual. 
rela do samba”. A Batalha de Confete contava com a participação maciça do público, que se deslocava de suas comunidades para o centro da cidade a fim de prestigiar a escola do bairro. O maior número de torcida e de gente na avenida do carnaval dava maior status para uma agremiação. Aquela que, com o "samba na voz do povo", atraísse mais gente na Batalha despontaria como uma das favoritas para o desfile daquele ano.

Mesmo quem não desfilava nas escolas de samba ia para a Batalha de Confete. Esse era o caso de Roberto (branco, magro, de 82 anos, vendedor aposentado). Segundo ele, apesar de não gostar de sambar, não perdia uma Batalha, pois aquele era um momento de festa, o "esquenta" para o carnaval. Os domingos da Batalha de Confete eram a garantia de ouvir os sambas mais populares dos carnavais passados, sambas vitoriosos e que, por si só, já asseguravam a animação da assistência. Alguns de meus interlocutores, sobretudo os que, ao tempo da pesquisa, estavam na faixa dos 50 aos 60 anos, relembram que a Batalha de Confete era a "oportunidade de começar os primeiros flertes e as primeiras paqueras" com aqueles que, como eles, iniciavam no "mundo do carnaval" e começavam a elaborar principiantes desejos homoeróticos.

Eles contam que não existiam espaços para a convivência de pessoas com conduta homossexual na cidade, na forma do que se convencionou chamar de "mercado GLS". Portanto outras estratégias que envolviam, sobretudo, o flerte e a paquera em espaços públicos eram as mais utilizadas por eles. Em vista disso, o "tempo do carnaval", que tinha início logo depois da metade do ano, mas que se tornava mais frequente entre dezembro e janeiro, era o momento em que se podia efetivamente "tentar a sorte" no mundo dos desejos. Afinal, "quem estava na Batalha de Confete, quem estava nos ensaios, quem participava da vida do barrocão, era do lance", lembra Roberto.

Mais do que lembrar "lances" do "tempo de antigamente", as pessoas com quem conversei na região guardam o carnaval como um lugar que, ao ser rememorado, permite-lhes sorrir. A simples pronúncia da palavra carnaval já produzia uma mudança de expressão no rosto. De um semblante sério, em alguns momentos desconfiado ou triste, nascia um sorriso quando se pronunciava a palavra. A memória da alegria do carnaval encontra eco nas observações de Maria Laura Viveiros de Castro Cavalcanti (2011, p. 245): "quem quiser pode participar, se fantasiar, pular nas ruas ou nos bailes, dançar, tocar, competir ou se exibir num desfile festivo, cantar pra valer, até se exaurir".

Em grande medida, isso se explica, como pontuam alguns interlocutores, por se tratar de um tempo diferente do resto do ano. Não um tempo de sus- pensão, nem de inversão, mas um tempo de novas oportunidades, de novos protagonismos - um kairós dentro do cronos. O carnaval propicia, então, a reinvenção da realidade, que, durante esses dias, adquire uma forma alternativa, diferente daquela que de fato apresenta nos demais dias do ano. Esse tempo especial, porém, é um tempo em que os problemas não deixam de existir. Mas, nos dias de duração dessa vida festiva, o imaginado pode ser, mais que imaginado, posto em prática.

Por fim, conforme se depreende das falas dos interlocutores, as lembranças sobre o carnaval parecem girar em torno da ideia de realização. O kairós do carnaval é um tempo de realização pessoal e de realização coletiva, um tempo de realizar fantasias, de realizar(se). As realizações possíveis no carnaval estão na fronteira do tempo cronos, um tempo permanente ao longo dos dias que sucedem a festa.

\section{Considerações finais}

As lembranças aqui evocadas, as construções e elaborações dos meus contatos de campo aparecem sempre com uma marcação clara de que o carnaval é um tempo jovem. Foram poucas as vezes, ao longo das conversas que tivemos, em que as figuras que apareciam em destaque nas falas eram velhas. Tanto aqueles que serviram de exemplo aos meus interlocutores, como eles próprios, à medida que o tempo vai transcorrendo, vão se afastando do mundo do carnaval e recolhendo-se nos limites da casa.

Os interlocutores mais velhos, por exemplo, não participam mais dos festejos carnavalescos, pois entendem que sua contribuição já teria sido dada. E que o tempo deles já passou; o tempo presente é dos jovens. O envelhecimento vai, segundo o que observei, afastando-os do carnaval. Em momentos esparsos, ou mesmo no desfile, eles aparecem. Muito mais como figuras homenageadas, pontualmente, pelas contribuições passadas, do que, propriamente, por serem agentes ativos no cotidiano da organização da festa. São lembrados em função de seu papel "nos carnavais de antigamente", não porque ainda tenham algum protagonismo.

A regra, pode-se concluir, é as pessoas velhas tornarem-se espectadoras do carnaval e ocuparem-se de guardar na memória as experiências acumuladas nos processos de construção e vivência da festa em tempos idos. Assim, extraordinariamente, elas podem contar suas memórias para um ou outro que esteja ávido por saber desses quase interditos de outrora.

Esses curiosos, quem sabe, perceberiam que o carnaval não é, como propunham os primeiros estudos na área, um momento de suspensão ou inversão 
do tempo ordinário. É, sim, um momento de tensão entre cronos e kairós, em que kairós reina absoluto durante os festejos de Momo. Entre os muitos acontecimentos desse tempo fechado em si mesmo, constam os encontros eróticos e sexuais, as descobertas, os amantes, menos discriminação, maior visibilidade ou mesmo a possibilidade de conquista de um lugar de dignidade, o glamour.

O carnaval, kairós que procurei analisar neste artigo, vem dando conta dessas relações que configuram sentido a uns e outros no decorrer do processo a que se submetem. Mas que processo seria esse? Retomando algumas teorias, esse processo diz respeito às transformações sociais que edificaram novos lugares para as condutas homossexuais (Fry; MacRae, 1982; Carrara, 2005), através do manejamento de distintos regimes de visibilidade (Meccia, 2011). Esse processo inclui também o significado surpreendente adquirido pelo carnaval num contexto em que, diferente do que acontece nos grandes centros urbanos, não existe $o$ chamado "mercado GLS", identificado - e problematizado - por França (2012).

Enfim, apesar dos sentidos conferidos aos sujeitos que analiso, o kairós do carnaval não é exclusivo desses sujeitos, que costumam estar apenas em espaços soturnos. O interessante desse kairós é que ele permite contatos entre diferentes, ainda que as estruturas se mantenham e as luzes voltem a iluminar aqueles mesmos espaços durante o tempo cronos, até a oportunidade de um novo kairós. E, apesar dessa continuidade, também é possível ver, com o carnaval, uma sensível mudança do "lugar social da homossexualidade" (Carrara, 2005), sobretudo, porque, nesse lugar em que transitam meus interlocutores, não estou referenciando apenas discriminação, estigma, preconceito e desqualificação. Ali existem também possibilidades de revelação de múltiplas potências, relações, mudanças, reformulações, reestruturações, enfim é permitido a esses sujeitos brincar jocosamente no kairós com as dores que os acometem durante a vigência do interminável cronos.

\section{Referências}

BASSIT, Ana Zahira. O curso de vida como perspectiva de análise do envelhecimento na pós-modernidade. In: DEBERT, Guita Grin; GOLDSTEIN, David (Org.). Políticas do corpo e o curso da vida. São Paulo: Mandarim, 2000.

CARRARA, Sérgio. O Centro Latino-Americano em Sexualidade e Direitos Humanos e o "lugar" da homossexualidade". In: GROSSI, Miriam Pillar et al. (Org.). Movimentos sociais, educação e sexualidades. Rio de Janeiro: Garamond, 2005.
CAVALCANTI, Maria Laura Viveiros de Castro. Baianas e Velha Guarda: corpo e envelhecimento no carnaval carioca. In: GOLDENBERG, Mirian (Org.). Corpo, envelhecimento e felicidade. Rio de Janeiro: Civilização Brasileira, 2011.

DA MATTA, Roberto. Carnavais, malandros e heróis. Rio de Janeiro: Zahar, 1979.

DEBERT, Guita Grin. A reinvenção da velhice: socialização e processos de privatização do envelhecimento. São Paulo: Editora da Universidade de São Paulo, 2004.

FEATHERSTONE, Mike; HEPWORTH, Mike. Envelhecimento, tecnologia e o curso da vida incorporado. In: DEBERT, Guita Grin; GOLDSTEIN, David. (Org.). Políticas do corpo e o curso da vida. São Paulo: Mandarim, 2000. p. 109-132.

FOUCAULT, Michel. Michel Foucault: politics, philosophy, culture: interviews and other writings (1977-1984). KRITZMAN, Lawrence (Org.). New York: Routledge, 1988.

FOUCAULT, Michel. A ordem do discurso. 7. ed. São Paulo: Loyola, 2001.

FOUCAULT, Michel. Ditos e escritos. Rio de Janeiro: Forense Universitária, 2004. v. 5.

FOUCAULT, Michel. A verdade e as formas jurídicas. Rio de Janeiro: Nau, 2005.

FOUCAULT, Michel. A coragem da verdade: o governo de si e dos outros. São Paulo: WMF Martins Fontes, 2011. v. 2. Curso no Collège de France (1983-1984).

FRANÇA, Isadora Lins. Consumindo lugares, consumindo nos lugares: homossexualidade, consumo e subjetividades na cidade de São Paulo. Rio de Janeiro: Eduerj, 2012.

FRY, Peter; MacRAE, Edward. Mesmo no carnaval baiano, “cada macaco no seu galho". Lampião da Esquina, ano 1, n. 1, mai.-jun. 1978.

FRY, Peter; MacRAE, Edward. Para inglês ver: identidade e política na cultura brasileira. Rio de Janeiro: Zahar, 1982.

GIELE, Janet; ELDER JÚNIOR, Glen. Life course research: development of a field. In: Methods of life course research: qualitative and quantitative approaches. Califórnia; Londres: Sage, 1998. p. 5-27.

GONTIJO, Fabiano. O Rei Momo e o arco-íris: homossexualidade e carnaval no Rio de Janeiro. Rio de Janeiro: Garamond, 2009.

GREEN, James Naylor. Além do carnaval: a homossexualidade masculina no Brasil do século XX. São Paulo: Ed. Unesp, 2000.

HARA, Tony. Ensaios sobre a singularidade. São Paulo: Intermeios; Londrina-PR: Kan, 2012.

MECCIA, Ernesto. Los últimos homosexuales: sociología de la homosexualidad y la gaycidad. Buenos Aires: Gran Aldea, 2011.

MOODY, Harry Rick. Overview: what is critical gerontology and why is it important? In: COLE, Thomas R. et al. (Org.). Voices and visions old aging: toward a critical gerontology. New York: Springer Publishing Company, 1993. 
PASSAMANI, Guilherme Rodrigues. Batalha de Confete no "Mar de Xarayés": condutas homossexuais, envelhecimento e regimes de visibilidade. Tese (Doutorado em Ciências Sociais) - Instituto de Filosofia e Ciências Humanas, Universidade de Campinas, Campinas-SP, 2015.

QUEIROZ, Maria Isaura Pereira de. Carnaval brasileiro: o vivido e o mito. São Paulo: Brasiliense, 1992. 


\title{
Kairós and Carnival: life course, schemes visibility and homosexual condutc in Mato Grosso do Sul's Pantanal
}

\begin{abstract}
In this article, I present the kairós' particularity in Corumbá's (MS) carnival understood by kairós a special time, time of opportunities, one that allows the construction of something different from the ordinary. Through an ethnographic research conducted between 2012 and 2014 in the Mato Grosso do Sul Pantanal region, I highlight the importance of carnival to people with homosexual conducts, that took part in my investigation, especially older ones. First, starting from the notions of cronos and kairós, I show how carnival has been constituted as a time of protagonism and misfortunes. Up next, I highlight how carnival is comprehended by the interlocutors and literature on the subject. Finally, the article moves to the memories that constitute, in local imaginary, the carnival as a place of "bichas", as well as an association of the event time with youth.
\end{abstract}

Keywords: carnival, life course, homosexual behavior, sexuality, Pantanal (Brazil).

\section{Kairós y Carnaval: curso de la vida, regímenes de visibilidad $y$ conductas homosexuales en el Pantanal de Mato Grosso do Sul}

\section{Resumen}

En este artículo presento la particularidad del kairós del Carnaval en Corumbá, entendiéndose por kairós un tiempo especial, tiempo de oportunidades, aquel que permite la construcción de algo diferente a lo ordinario. A partir de una investigación etnográfica llevada a cabo entre 2012 y 2014 en la región del Pantanal de Mato Grosso do Sul, resalto la importancia del carnaval para las personas con conducta homosexual, especialmente los mayores, que compusieron mi investigación. Primeramente, trabajando con las nociones de cronos y kairós, muestro como el carnaval constituye un tiempo de protagonismos. Justo después, destaco como el carnaval es entendido por mis interlocutores y por la literatura del área. Por último, analizo los recuerdos que, en el imaginario de la región, construyen el carnaval como el lugar de las "bichas", y llevan a una asociación del tiempo de la fiesta con la juventud.

Palabras clave: carnaval, curso de la vida, conducta homosexual, sexualidad, Pantanal (Brasil).

Data de recebimento do artigo: 02/11/2016 Data de aprovação do artigo: 01/04/2017 
